ISSN: 0213-2052 - eISSN: 2530-4100

DOI: https://doi.org/10.14201/shha202139425454

\title{
HEREJES ESPECTRALES, JUDÍOS \\ HERMENÉUTICOS Y ÁNGELES CELESTIALES \\ PARA INSTRUIR CRISTIANOS. EL DE UIRGINITATE \\ DE ILDEFONSO DE TOLEDO
}

\section{Spectral Heretics, Hermeneutical Jews and Celestial Angels for the Education of Christians. The De uirginitate of Ildefonsus of Toledo}

Dolores CASTRO

(IMHICIHU-CONICET / UNGS)

dolorescastro@gmail.com

ORCID: https://orcid.org/0000-0002-8790-3821

Rodrigo LAHAM COHEN

(IMHICIHU-CONICET/UBA/UNSAM)

R.lahamcohen@conicet.gov.ar

ORCID: https://orcid.org/0000-0003-3193-7747

Fecha de recepción: 13-10-2020 Fecha de aceptación: 1-3-2021

RESUMEN: De uirginitate Sanctae Mariae de Ildefonso de Toledo ha sido objeto de numerosos estudios, especialmente dedicados a establecer su finalidad y audiencia. Las principales perspectivas han oscilado entre reconocer como destinatarios a judíos, a cristianos que habían sido judíos o a cristianos sin pasado judío. En este marco historiográfico, nuestra propuesta consiste en considerar al De uirginitate como parte de una estrategia pedagógica destinada principalmente a instruir al clero y, por extensión, a 
la comunidad cristiana en general. Desde esta perspectiva, herejes y judíos funcionaron como verdaderas herramientas educativas que, al identificar el error, enseñaban los pilares de la doctrina cristiana y contribuían a la afirmación de la unidad e identidad de las comunidades que integraban el reino visigodo.

Palabras clave: reino visigodo; identidad cristiana; judíos; Biblia.

ABSTRACT: Ildefonsus of Toledo's De uirginitate Sanctae Mariae has been studied from different points of view, specially aimed at establishing its purpose and audience. Three main perspectives can be distinguished: the work was either intended for Jews, for Christians who had been Jews, or for Christians without a Jewish past. Within this historiographical framework, our proposal considers De uirginitate as part of a pedagogical strategy designed mainly to instruct the clergy and, by extension, the Christian community in general. From this perspective, heretics and Jews have functioned as true educational tools that, by identifying the error, have taught the pillars of the Christian doctrine and contributed to the affirmation of the unity and identity of the communities within the Visigothic kingdom.

Keywords: Visigothic kingdom; Christian identity; Jews; Bible.

\section{INTRODUCCIÓN}

Audite me itaque, cum antiquitatis auctoribus Moyses antiquiora loquens, cum prophetis Isaias potentiora uaticinans, cum euangelistis Matthaee prima pronuntians, cum apostolis electe Petre insignia praedicans, intra omnem ecclesiam Dei felicium turba doctorum uera dicens atque salutaria disserens, haec me pro certo credere, quae credenda intenditis praedicare, haec me piissime confiteri, quae ipsi ueraciter confitemini, haec me ipsum adnuntiare, quae adnuntianda docetis audire, his posse quo possum ueram oboedientiam dare, quibus toto posse uniuersam ecclesiam Dei decernitis oboedire ${ }^{1}$.

Ildefonso de Toledo (607 d. C.-667 d. C.) expresó, con estas palabras, la noción eclesiástica de continuidad; una tradición imaginada desde Moisés y los profetas hasta los evangelistas, apóstoles y doctores de la Iglesia que había anunciado, vaticinado y predicado, en su lógica, la Verdad. En efecto, desde los primeros siglos cristianos, incontables esfuerzos fueron destinados a forjar esta unidad, por ejemplo, al impulsar la creación de

1. De uirg., praef. 29-38. Utilizamos en este trabajo la edición más reciente de la obra a cargo de Valeriano Yarza Urquiola, De uirginitate. 
un único canon, que, tras un período de extensas controversias y polémicas, terminó admitiendo los escritos veterotestamentarios en su seno. Asimismo, otros tantos esfuerzos se empeñaron en comunicar y enseñar un mensaje: una sola era la Palabra de Dios, una sola la Escritura Sagrada y una sola era la Verdad. Más allá de la cantidad de textos y de la pluralidad de tradiciones y autores involucrados en su redacción, Antiguo y Nuevo Testamento se presentaban como una sola Biblia, una unidad, sin contradicción ni oposición, inspirada por la divinidad. Un vínculo indisociable había sido construido entre ambos: el primero no solo era concebido como promesa y profecía del segundo, sino que, además, el segundo era presentado como necesario para comprender al primero. Por lo tanto, desde la interpretación cristiana, el Antiguo Testamento se convirtió en la prefiguración del Nuevo y el Nuevo en la clave hermenéutica del Antiguo, que adquiría ahora un nuevo sentido a la luz de una lectura cristocéntrica $^{2}$.

El fragmento citado corresponde al prefacio que acompaña a De uirginitate Sanctae Mariae, una obra escrita por Ildefonso en la segunda mitad del siglo VII, probablemente en un período anterior a su elevación al episcopado toledano en el año $657^{3}$. Desde muy joven, Ildefonso había ingresado en el monasterio de Agali, un establecimiento próximo a la capital visigoda, donde consagró sus días a la contemplación y a la vida en comunidad. Su formación monástica temprana y su posterior

2. Para una orientación general sobre el tema, enviamos a Trebolle Barrera, La Biblia, y Paget y Schaper, The New Cambridge.

3. La mayoría de los especialistas coinciden en situar la obra en una etapa anterior a la ocupación de la sede episcopal toledana en 657. Para un tratamiento exhaustivo, véase el estudio de Yarza Urquiola, De uirginitate, 21-27, 51-58. Este argumenta a favor de dos momentos en la redacción del tratado: una primera parte habría estado dedicada a combatir la creencia judía en directa relación con el concilio VIII de Toledo (653) y otra posterior, a exaltar la virginidad mariana, en el marco del traslado de la festividad de la Anunciación al 18 de diciembre, decretado en el concilio X de Toledo (656) con el propósito de instalar una única fecha para todo el territorio peninsular. Según Yarza Urquiola (38-41), Ildefonso aspiró, en principio, a constituir un tratado adversus Iudaeos al estilo del De fide de Isidoro de Sevilla. Al reformularlo diluyó el tono antijudío precisamente en un momento en el que, según una parte de la crítica, el episcopado toledano había suavizado la presión sobre los judíos. Si bien esta tesis es sugerente, no creemos que existan elementos definitorios para aseverar la existencia de una redacción en dos temporalidades diferentes, así como tampoco de un intento por moderar el tono antijudío dado que la obra posee pasajes de una violencia inusitada contra los judíos (véase, a modo de ejemplo, De uirg., 428-447). Por último, incluso si se aceptara la doble temporalidad de producción (amparándonos, por ejemplo, en la falta de menciones de la virginidad de María en el prefacio), debemos recordar que Ildefonso terminó ensamblando el texto y presentándolo como una unidad por lo que es válido considerar que, desde su punto de vista, era efectivamente una unidad. 
desempeño como abad dejaron una viva impronta en su actividad pastoral, en sus escritos y enseñanzas, constantemente atravesados por una perspectiva que alentaba la adopción de una conducta rigurosa, dictada por los más severos preceptos y valores cristianos 4 . Pero estas normas, prácticas y formas de entender la Palabra Divina debían ser transmitidas, enseñadas y reforzadas en las distintas comunidades que integraban el reino de Toledo. En este contexto, las iglesias locales canalizaron la educación cristiana a través de un conjunto de medios y mecanismos de distinta naturaleza: desde la agenda litúrgica hasta la producción literaria, las palabras y los gestos se combinaron para hacer llegar un mensaje a una audiencia numerosa y heterogénea.

El primer paso consistía en instruir al clero: a los sacerdotes, presbíteros, diáconos y a toda la jerarquía eclesiástica que había sido encomendada con la tarea de difundir la doctrina. El hecho de que una multiplicidad de cánones conciliares hayan insistido en esta cuestión demuestra la vigencia de una preocupación que inquietó constantemente a las elites eclesiásticas del reino 5 . En otros tiempos había sido el obispo Isidoro de Sevilla quien había encarado la tarea de preparar y formar al cuerpo eclesiástico tanto en las verdades bíblicas y doctrinales como en los deberes y responsabilidades que afectaban a cada oficio ${ }^{6}$. Desde Toledo, Ildefonso retomaba esta iniciativa destinada principalmente a la formación del clero, adaptada a renovados contextos e intereses. Los tradicionales métodos de trabajo y principios hermenéuticos, otrora diseñados para conocer, interpretar y comunicar la letra bíblica, fueron actualizados y ajustados a las nuevas circunstancias.

4. Acerca de Ildefonso y el De uirginitate véanse, también: Madoz, "San Ildefonso"; Balleros Mateos, El tratado; Beltrán Torreira, "San Ildefonso»; Muñoz León, «El uso»; Del Valle, «El tratado»; Pozas Garza y Moreno García, «Una controversia», y Codoñer Merino, La Hispania.

5. Los concilios visigodos exhiben un conjunto variado de cánones destinados a uniformizar la liturgia y la administración de los sacramentos (Toledo III, c. II; Toledo IV, c. II, VI-VIII, entre otros), a delimitar las funciones y atribuciones de la jerarquía eclesiástica (Toledo IV, c. XIX-XXVII), a regular el comportamiento (Toledo III c. V; Toledo IV c. XXI; Toledo VIII c. V, IX) y a fomentar la educación clerical. Sobre este último punto, por ejemplo, destacan el canon XXV de Toledo IV (633), que exhortaba al cuerpo episcopal a conocer las Escrituras y los cánones, y el canon VIII de Toledo VIII (653), que hacía referencia a la ignorancia y a la insuficiente preparación de los clérigos.

6. En torno a Isidoro de Sevilla, la bibliografía es ingente. Véanse, entre otros, Fontaine Isidore de Séville et la culture e Isidore de Séville. Genèse et originalité; Cazier, Isidore de Séville; Codoñer Merino, «El mundo cultural»; Dell'Elicine, En el principio; Fear y Wood, Companion to Isidore of Seville e Isidore of Seville and his Reception; Castro, "The Bishop". 
Entre los dispositivos hermenéuticos empleados entre quienes aspiraban a formar al clero hispano, la figura del judío ocupaba un lugar importante. No se trataba del judío de carne y hueso, sino del judío atemporal. Judíos hermenéuticos, discursivos, modélicos, espectrales, teológicos, retóricos, de papel o como prefiramos llamarlos ${ }^{7}$. Figuras deliberadamente disociadas de la realidad social pero con impacto en esta porque, precisamente, operaban como modelos para señalar cómo debía ser el comportamiento cristiano esperado por el clero, en oposición al de tales judíos de papel.

Es pertinente recordar, antes de continuar, que el término «judío», para el período de Ildefonso, poseía una carga semántica polisémica. Tanto en las leyes compiladas en el Liber Iudiciorum (654) como en diversos cánones conciliares coexistían Iudaei con Iudaei baptizati ${ }^{8}$. Es que a partir de la conversión forzosa dictaminada por Sisebuto la situación se había tornado compleja. La legislación nunca denominó a los cristianos que provenían del judaísmo como cristianos y extendió sobre estos un manto de sospecha continuo que llegaría hasta la propia disolución del orbe visigodo en los inicios del siglo VIII. "Judío» en la compilación legal promulgada en 654 podía referir tanto a un judío como a un cristiano que había sido judío. Por otra parte, la propia legislación, avanzado ya el siglo VII, continuaba diferenciando "judíos convertidos" de "judíos no convertidos" dando a entender el carácter incompleto de la conversión impuesta por Sisebuto y reiterada por otros monarcas ${ }^{9}$. La propia epigrafía judía, si bien escasísima, da señales de continuidad del judaísmo ${ }^{10}$.

7. Si bien estas categorías significan aproximaciones diversas por parte de la historiografía, comparten la noción de que una parte importante de las referencias al término ejudío» tiene un carácter estrictamente simbólico y cumple funciones discursivas no asociadas a la realidad de los judíos y judías contemporáneos/as al momento de enunciación. Para "Paper Jew", véase Biddick, "Paper Jews»; para "Hermeneutical Jew", Cohen, Living Letters; "Spectral Jew», Kruger, The Spectral Jew; "Virtual Jew». Tomasch, «Postcolonial Chaucer». Un buen resumen de este tipo de debates en Fredriksen, "Roman Christianity".

8. La gran mayoría de los trabajos que acometen el estudio del judaísmo en el período tardoantiguo dan cuenta de la polisemia del término judío en la legislación visigoda. Entre los más relevantes, resaltan Bachrach, "A Reassessment»; Gil, «Judíos y cristianos"; García Iglesias, Los judios; Orlandis, «Hacia una mejor»; García Moreno, Los judios; Cordero Navarro, "El problema»; González Salinero, Las conversiones y «Preaching and Jews»; Sivan, "The Invisible»; Bradbury, "The Jews»; Benveniste, "On the Language»; Martin y NemoPekelman, "Les Juifs»; Stocking, "Early Medieval»; Martin, «La degradación»; Laham Cohen y Pecznik, "Iudaei».

9. Además de los trabajos mencionados en la nota anterior, un análisis original de la continuidad de la presencia judía en Hispania en González Salinero, «Los judíos».

10. Es muy conocida la inscripción narbonense de los hijos de Paragoro (JIWE I 189), ישראל quien no solo hizo grabar una menorá en la tumba sino que también hizo inscribir 
La revitalización de la legislación antijudía, con la promulgación del Liber Iudiciorum impulsada por Recesvinto, presentaba al monarca no solo como quien resguardaba la unidad del reino y protegía la ortodoxia, sino también como el principal bastión contra lo percibido en su tiempo como judaísmo y/o judaización. Asimilaba su conducta a la de otros reyes que, como Recaredo o Sisebuto, también habían acudido a la redacción de leyes para regular, controlar y limitar la situación de lo que entendían como judaísmo en territorio godo. La problemática judía - al menos eso sugiere la información legislativa - se mantenía firme en la agenda de la cúspide política y religiosa y por ello lo más probable es que, al escribir el De uirginitate, Ildefonso se haya hecho eco de los problemas vinculados a las inquietudes que afectaban a las elites de Toledo: consolidar la unidad y la integración del reino.

En continuidad con la tradición conciliar visigoda, Ildefonso contribuía con la embestida doctrinal vinculada al afianzamiento de la unidad religiosa. Al arremeter contra la figura del judío, retomaba un tópico ya clásico de la tradición patrística, pero, sobre todo, intervenía en un asunto vertebral de la agenda monárquica y conciliar. Reivindicaba el papel central e imprescindible del clero en el combate contra lo percibido como acción disgregadora del judaísmo, ofensiva en la cual, como hemos visto, el monarca también se arrogaba pleno protagonismo. Recordemos que en el concilio VIII de Toledo Recesvinto se había mostrado profundamente preocupado por la extensión de la "perfidia y apostasía judía". Su estrategia ofensiva, sin embargo, no fue acompañada por los obispos, quienes se limitaron a confirmar medidas ya promulgadas en Toledo IV. La misión del monarca contra cualquier disidencia religiosa - aparente o real- continuó un año más tarde con la promulgación del Liber, un cuerpo legislativo que despojaba a los «judíos» de sus derechos, civiles y religiosos, y obstaculizaba, para los «judíos no convertidos», la práctica de su religión, de sus ceremonias y ritos tradicionales.

\footnotetext{
El epitafio está explícitamente datado en tiempos del rey Égica mostrando la continuidad del asentamiento judío en territorio bajo control visigodo. El único aspecto problemático de este testimonio es, precisamente, su ubicación en la Galia narbonense, región especial dentro del territorio visigodo donde los judíos, según palabras de Julián de Toledo y la propia legislación canónica, recibían un trato diferente. Sobre la política visigoda frente a los judíos en Narbona, véase el original análisis de Martin, «Los judíos». En relación al repertorio arqueológico, si bien la controversia en torno al edificio hallado en Elche aún sigue abierta, en los últimos años ha ganado más espacio la idea de que efectivamente allî hubo una sinagoga. No obstante, incluso aceptando el uso sinagogal del edificio, el material no ofrece claves para entender los fenómenos aquí estudiados. Véanse, entre otros, Poveda Navarro, «El edificio»; Walsh, «Reconsidering», y Bar-Magen Numhauser, «La identificación».
} 
Ildefonso, sin embargo, no hace referencia alguna a estas realidades en el De uirginitate. No lo hace porque, lo anticipamos aquí, su objetivo principal no son los judíos. Del mismo modo que tampoco lo son los seguidores de Helvidio o Joviniano, a los que podríamos llamar, para el período, herejes espectrales ${ }^{11}$. Si bien judíos y herejes son protagonistas del texto, lo son solo en función del objetivo más importante del obispo: los cristianos y su comportamiento.

Pero más allá del objetivo de Ildefonso, lo cierto es que, con el De uirginitate, la cuestión judía volvía a escena. El hombre de Agali impulsaba una forma de enseñar y difundir el mensaje ortodoxo. Si la religión era considerada un poderoso elemento de cohesión social, también lo era toda creencia que atentara contra ella. En otras palabras, enseñar el contraste, identificar y visibilizar el error contribuían tanto a evitar su propagación como a afianzar la doctrina impartida por la Iglesia. La definición de las creencias como erróneas, blasfemas y nefandas, es decir, el acto de calificar las opiniones contrarias a la verdadera fe, se incluía dentro de las competencias eclesiásticas, ejercidas principalmente por los obispos, quienes se erigían en guardianes de la ortodoxia e intermediarios entre la Palabra revelada y la multitud de los fieles ${ }^{12}$.

Nuestra propuesta en estas páginas consiste en explorar la construcción y el uso del adversario en De uirginitate Sanctae Mariae, una obra que revela tanto la actualidad como la funcionalidad de los, para el período, ya multiseculares tópicos de la literatura cristiana. El objetivo principal es analizar la adaptación de una modalidad de enseñanza que hacía de la identificación y exhibición del error —encarnado en el adversario- una forma de transmitir los principales pilares de la religión cristiana, al distinguir entre la verdad y la falsedad, entre la ortodoxia y el engaño. En este sentido, herejes y judíos sirvieron a un mismo propósito: encarnar las voces de la contradicción y la desviación, constituir los blancos de una embestida doctrinal infalible, que, al mismo tiempo que descalificaba toda posición adversa, afianzaba los fundamentos de la verdadera fe. Esta iniciativa, sin embargo, se extendía más allá de la correcta argumentación en favor de importantes puntos doctrinales. Ildefonso mostraba un sólido conocimiento de la Biblia y se presentaba como el principal defensor de la ortodoxia y promotor de la fe cristiana. Desplegaba un conjunto de técnicas retóricas y estilísticas (sinonimia, reiteración, oposición) que construían no solo un mensaje contundente, sino una palabra

11. Reformulamos, así, la categoría de spectral Jew acuñada por Kruger, The Spectral Jew.

12. Véase González Salinero, «El obispo». 
autoritativa, que lo situaban como un ejemplo en el dominio del saber y un referente ineludible en la lucha contra quienes señalaba como herejes.

Al enseñar la unidad bíblica y apoderarse del pasado judío, de sus escrituras y profetas, Ildefonso no solo continuaba una tradición de larga data actualizando el paradigma del adversario judío y, con él, el de todo un pueblo que había sido privado de su antigua condición de elegido; al mismo tiempo, afianzaba la identidad cristiana afirmando la unidad de su feligresía, es decir, de aquellos que vislumbraba como elegidos que, por medio de la gracia y acompañados por la Iglesia, esperaban, una vez llegado el Juicio Final y el fin del mundo en la tierra, la vida eterna in saecula saeculorum.

\section{Helvidio y Joviniano: ANTiguOS ADVERSARIOS, NUEVOS TIEMPOS}

En De uirginitate Ildefonso adoptaba desde el comienzo una posición de combate y anunciaba lo que concebía como su misión: buscar la Verdad y reivindicar a Dios frente a todo adversario que insistiera en su negación y profanación ${ }^{13}$. Las primeras secciones de su tratado las dedicó a rebatir las posiciones heterodoxas de Joviniano y Helvidio, dos teólogos del siglo IV que habían rechazado en su tiempo la virginidad de María. El primero había impugnado la pureza de la Virgen en el parto; el segundo su perpetuidad. Ambas interpretaciones, sin embargo, habían sido objetadas y refutadas por Jerónimo, también durante la cuarta centuria, en dos obras apologéticas: Aduersus Heluidium de Mariae perpetua uirginitate y Aduersus Iouinianum ${ }^{14}$. No obstante, a partir de Jerónimo, ambos personajes fueron olvidados por los Padres de la Iglesia, más allá de algunas menciones dispersas. ¿Por qué, entonces, reanudar esta controversia tres siglos más tarde? ¿Se podría considerar acaso un resurgimiento de estas herejías en Toledo? ¿Por qué motivo reaparecían en la obra de Ildefonso?

La presencia de estos antiguos oponentes se enmarcaba en una estrategia discursiva ya clásica para el período: la constitución de oponentes retóricos con el fin de alcanzar un objetivo específico en el auditorio cristiano. Así como el judío retórico sirvió para constituir (y reforzar) la identidad cristiana, Joviniano y Helvidio pueden ser catalogados como

13. De uirg., praef. 92-94: «... solis aduersis Dei resistens, solis profanatoribus et profanationibus cunctis obuius existens, solis contradicentibus ueritati amore ueritatis aduersus...”.

14. Sobre las controversias con Helvidio y Joviniano véase Kelly, "Jerome»; Hunter, "Resistance», "Helvidius» y Marriage. 
beresiarcas espectrales, cuyo fin discursivo excedía plenamente la confrontación de tales personajes o posibles seguidores de estos.

El hombre de Agali se dirigía a sus imaginarios adversarios por medio de expresiones exhortativas formuladas en la segunda persona del singular, emulando la forma característica de la literatura polémica. A partir de las invectivas y amenazas a los herejes, Ildefonso proyectaba el mensaje a una audiencia de mayor tamaño, advirtiendo a todo aquel que se animara a repetir las mismas cosas. Desde esta perspectiva, por lo tanto, Joviniano y Helvidio eran utilizados como dispositivos pedagógicos, pues representaban las concepciones erróneas que no debían ser reproducidas ni aceptadas por ningún miembro de la ecclesia. Esto le permitía a Ildefonso presentar de forma breve la creencia herética y exponer las consecuencias sin duda negativas y terribles que le esperaban a todo aquel que transgrediera el dogma. Un ejemplo claro se observa en la siguiente exhortación a Joviniano:

Audi tu, percipe tu, Iouiniane, corde sapito, fatue, praecordiis cognosce, stulte, sensu disce, caduce. [...] si uirgini nostrae aut generationem aut integritatem adimis, grandi dedecore Deo iniuriam facis ${ }^{15}$.

En primer lugar, notemos el despliegue de calificativos que Ildefonso empleaba para referirse a un adversario que, desde un comienzo, se presenta derrotado. En efecto, el resto de la sección exhibe una larga lista de atributos negativos y ofensivos que caracterizaban típicamente al hereje. También Helvidio, más adelante, es representado de acuerdo a los mismos parámetros, como un hombre sin pudor, carente de honestidad y vergüenza $^{16}$. Si bien las palabras del toledano aparecían hilvanadas en extensas cadenas sinonímicas y repetitivas, este buscaba la claridad en la comunicación: defender y difundir aquello que catalogaba como error. Negar la virginidad in partu de María significaba, en su lógica, atentar contra el mismo Dios. Aun más, dejando momentáneamente a Joviniano en un segundo plano, Ildefonso se dirigía a un destinatario colectivo para advertir que el castigo era extensible a todos los mortales que se atrevieran a pronunciar y diseminar semejantes atrocidades: «Hebetescat, oro, hebetescat cor talia meditans, obmutescat os talia proloquens, haereat lingua talia promens, non adspiret sermo talia narrans ${ }^{17}$.

15. De uirg., 48-49 y 56-57.

16. De uirg., 99-101: "Audi ergo et tu, Heluidi, ad me adtende, impuderate, me absculta, impudice, me intuere, inhoneste, me conspice, inuerecunde...».

17. De uirg., 64-66. 
En segundo lugar, el toledano se vale de sus adversarios para construir su propio papel como egregio defensor de la fe, al situarse inmediatamente en la primera línea de batalla alzando su voz desafiante y combativa. Esta faceta se revela, por ejemplo, en la siguiente embestida destinada a Helvidio:

Nolo ius maiestatis inrumpas, ne possessionem Dei conuexare ausu pertemptes, ne mansionem diuinitatis noceas praesumptione contemptionis, ne domum Domini iniuriis corruptionis confodias, ne portam domus Dei, eius exitu clausam, a quocumque posse adiri contendas ${ }^{18}$.

De esta manera, el uso de adversarios como Joviniano y Helvidio otorgaba a Ildefonso la posibilidad de desplegar su erudición y conocimiento doctrinal, y también de apuntalar su posición como firme protector de aquellos pilares de la fe que consideraba centrales: la Iglesia y, especialmente, María ${ }^{19}$.

18. De uirg., 106-110.

19. El culto mariano conoció durante la Antigüedad Tardía un notable desarrollo en Bizancio, principalmente en Constantinopla. La figura de la Virgen estuvo en el centro de los debates teológicos que a lo largo de los siglos IV y V mantuvieron en vilo a teólogos, obispos y emperadores. De hecho, el objetivo principal del Concilio de Éfeso en 431 había sido discutir la caracterización de María como madre de Dios, un tópico estrechamente relacionado con la divinidad de Cristo. Para algunos especialistas, incluso, este concilio significó un punto de inflexión en el desarrollo e impulso de la piedad mariana, un catalizador de un culto que aunque ya existente ganó significativo impacto (Shoemaker, Mary). En Occidente, en cambio, el despliegue del culto mariano no conoció la misma intensidad. Fue en Roma donde la devoción a la Virgen mostró su vigor principalmente en el arte, en la liturgia y en las nuevas iglesias dedicadas a ella (Rubin, Mother, 95-99). Acerca del culto mariano, véanse también Brubaker y Cunningham, The Cult, y Maunder, The Oxford Handbook. Sobre el desarrollo de la liturgia mariana en Hispania, véanse, entre otros: Ibáñez y Mendoza, "María", 343-421, e Ihnat, "Orígenes", 619-643. Esta última estudia el contexto histórico particular en el que se crea una nueva celebración en la península ibérica, establecida en 656 en el Concilio X de Toledo, explorando sus posibles influencias externas, principalmente los intercambios con otros centros religiosos como Bizancio y Roma. Según Ihnat, la presencia de Tajón de Zaragoza en Roma en la segunda mitad del VII habría coincidido con un contexto romano particular de impulso de la devoción mariana, caracterizado por la celebración de las cuatro fiestas marianas y el establecimiento del dogma de la virginidad perpetua de María en el Concilio de Letrán (649). Sobre este concilio, cf. Hurley, «Born Incorruptibly». La insistencia en la celebración de la fiesta mariana continuaría años más tarde, durante el reinado de Ervigio, en un nuevo contexto de revitalización de la legislación antijudía. Tanto es así que una ley atribuida a este monarca — LV 12.3.6 - establecía, entre las fiestas que los cristianos con pasado judío debían celebrar, festum virginis sancte Marie. Es de resaltar que tal festividad no aparece como algo excepcional sino que lo hace en el marco de una lista que incluye todas las festividades cristianas: Nacimiento, 


\section{El JudíO: El ETERNO ENEMIGO}

Probablemente Ildefonso no haya leído el Contra Celso de Orígenes ${ }^{20}$. Tampoco sabemos si alguna de las historias usualmente asociadas a la tradición literaria Toldot Yeshu llegaron a sus oídos o si, incluso, existían en la Hispania de su tiempo. Pero, más allá de ello, es obvio que Ildefonso sabía que los judíos habían rechazado y rechazaban la noción de virginidad mariana ${ }^{21}$. No es necesario ahora — volveremos sobre esto más adelante- determinar si el hombre de Agali estaba pensando en los judíos bíblicos, en los de su tiempo, en los cristianos que provenían del judaísmo o en todos a la vez. A fin de cuentas, quienes aparecen en el De uirginitate son judíos retóricos. Su voz es la de Ildefonso. O, en todo caso, la que la tradición adversus Iudaeos había ya constituido. Tales figuras, como anticipamos, servían para indicar a los cristianos cómo no debían comportarse. Eran dispositivos discursivos que cumplían el mismo objetivo que los espectros de Helvidio y Joviniano.

Ildefonso destinaba las más extensas secciones de su obra a atacar a los judíos, no solo en relación a la virginidad mariana, sino también al propio carácter mesiánico de Jesús. Presentaba un judío genérico y atemporal, sin nombre, sin identidad; una figura que con su anonimato simbolizaba a todo el colectivo judaico, acusado de incurrir en la injuria, la perfidia y la desobediencia. Este judío modélico —ciego, pérfido, que había negado y rechazado la Verdad- hacía su aparición en la obra

circuncisión y Epifanía de Cristo, Pascua, Octavas, Hallazgo de la Santa Cruz, Ascensión, Pentecostés y domingos. Vale resaltar, por otra parte, que en el corpus de leyes visigodas referidas a judíos y cristianos con pasado judío solo se encuentran dos menciones a María: la ya mentada ley y $L V 12.3 .14$ (también de Ervigio), donde se halla la Professio que debían repetir los conversos, en la cual María es referida, al pasar, en medio del credo.

20. Si nos guiamos por Martín, "La biblioteca", 279, Ildefonso no expresa en sus textos haber leído a Orígenes aunque el hecho de que el alejandrino haya sido leído (y empleado) por Isidoro y Julián debe ponernos en guardia sobre tal certeza. Es pertinente recordar que Orígenes, en Contra Celso I, 32 y I, 69, ponía en boca de los judíos la acusación de que Jesús había sido el fruto de un encuentro ilícito entre María y un soldado llamado Pantera. Tal relato también había sido retomado por Epifanio en Panarion 78.

21. Los relatos agrupados bajo el rótulo de Toldot Yeshu son narrativas tendientes a parodiar diversos aspectos del nacimiento, la vida y la muerte de Jesús. Entre ellos, tal como vimos en Orígenes y Epifanio, circulaba la idea de que María había tenido relaciones con un soldado llamado Pantera, unión de la que había nacido Jesús. De circulación interna y muy extendidos en el mundo medieval y moderno, es difícil datar la aparición de las narrativas en un formato estable. Una edición y análisis de los fragmentos y textos supervivientes en Meerson y Schäfer, Toledot. Vale recordar que el nombre de Pantera llegó también al Talmud. 
encarnando la maldad, la obstinación, la dureza y la falsedad. Y a este lanzaba el toledano su ritual de ataque:

Quid dicis, Iudaee, quid proponis, quid adstruis, quid obicis, quid obiectas? Ecce uirgo nostra ex stirpe tua est, ex genere tua est, ex radice tua est, ex traduce tua est, ex gente tua est, ex populo tua est, ex plebe tua est, ex natione tua est, ex origine tua est $^{22}$.

Y agregaba:

Verumtamen ex fide nostra est, ex credulitate nostra est, ex adsensu nostra est, ex reuerentia nostra est, ex honorificentia nostra est, ex laude nostra est, ex glorificatione nostra est, ex dilectione nostra est, ex amore nostra est, ex praedicatione nostra est, ex praeconio nostra est, ex defensione nostra est, ex uindicatione nostra est ${ }^{23}$.

Sinonimia, oposición y repetición eran las armas elegidas para emancipar a la Virgen de su pasado y de su origen judío. Si bien Ildefonso no se embarcaba en una tarea novedosa, su defensa de María adquiría especial relevancia en un contexto peninsular en el que Toledo consolidaba su posición como prominente centro urbano, político y religioso ${ }^{24}$. Ildefonso se convertía en un enérgico promotor de la devoción mariana e impulsaba desde Hispania su glorificación. Aquel confín occidental de la cristiandad latina se erigía también como un centro activo de su devoción. Ahora bien, en este proceso de exaltación del culto, los enemigos de la Virgen tenían un papel decisivo que cumplir. Joviniano, Helvidio y el judío - paradigmas del engaño, la falsedad y la mentira- reforzaban los valores ortodoxos y vigorizaban la defensa de los emblemas cristianos dentro de los cuales la madre de Dios ocupaba una centralidad inigualable. El diálogo con Gabriel ${ }^{25}$ y con la propia María, en cambio, representaban el polo opuesto, a partir del cual Ildefonso establecía una oposición

22. De uirg., 217-221.

23. De uirg., 221-226.

24. Acerca de la capitalidad de Toledo, véase, entre otros, Velázquez y Ripoll, "Toletum", 521-578, y Martin, La géographie.

25. Gabriel, responsable de haber anunciado el misterio de la encarnación a María, constituye - junto con la Virgen - un polo positivo a partir del cual Ildefonso acentúa el contraste. El ángel es presentado como el obediente servidor de Dios y mensajero divino por excelencia. Con la exaltación de estos aspectos, la figura de Gabriel se convierte en un modelo para el propio Ildefonso, quien, como vimos, había asumido la misión de difundir el mensaje que, desde el cristianismo, se consideraba como el único verdadero. Comunicar los arcanos divinos sin duda era una tarea que reclamaba la intermediación de una autoridad. 
discursiva clara entre el bien y el mal. En la invocación inaugural a María, el toledano se dirigía a su interlocutora apelando a un conjunto de calificativos y atributos que exaltaban su papel como engendradora del Hijo, pero también como el modelo femenino por excelencia: María era pura, íntegra, fiel, dichosa entre las mujeres y digna de gloria ${ }^{26}$. A esta imagen se agregaban más adelante nuevos caracteres — honestidad, santidad, nobleZa- ${ }^{27}$ que potenciaban aun más la presencia de la venerada Virgen.

La estrategia de Ildefonso, sin embargo, no estaba completa ni se limitaba únicamente a la defensa virginal de María. Recordemos que el público que podía acceder a este tipo de obras era reducido, integrado por un pequeño sector de la sociedad, el de las elites instruidas en la lectura y en el conocimiento necesario para comprender no solo el estilo del tratado, sino, además, su contenido doctrinal y bíblico. En este sentido, Ildefonso, en su embestida contra el judío imaginario no solo despojaba a este - y por extensión a todo su pueblo- de la figura de María, sino también de sus Escrituras. Por lo tanto, demostrar su error con ejemplos extraídos de su propio texto sagrado, una técnica frecuente en la literatura aduersus Iudaeos, constituía un paso más en la construcción de un combate que anticipaba desde un comienzo el triunfo de Ildefonso y la demostración de su erudición, dominio bíblico y manejo de técnicas antiguas. El experto toledano apelaba, entonces, a un conjunto de pruebas veterotestamentarias, de procedencia profética, que exponían el cumplimiento en el Nuevo Testamento de los vaticinios y promesas del Antiguo. De este modo, la continuidad testamentaria se presentaba como evidente a los ojos de los lectores: los profetas habían anunciado el misterio de Jesús que más tarde narrarían los evangelistas y predicarían los apóstoles. Desde esta perspectiva, De uirginitate proporcionaba al clero las herramientas exegéticas indispensables para orientar la interpretación veterotestamentaria en general y la comprensión de determinados pasajes en particular. Los testimonios de Isaías ${ }^{28}$ y Ezequiel $^{29}$, entre otros, se combinaban en la obra para afirmar la nobleza de María, siempre virgen, y exaltar su papel como madre y casa de Dios.

26. De uirg., 1-46.

27. De uirg., 85-92.

28. De uirg., 305-310: «Haec, in Isaia, uirga est ex radice Iesse, id est de genere eius exorta, uirgo quae florem hunc, Christum, spirituali tantum infusione sine hominis corruptionis accessione produxit. Item in Isaia haec sola terra fide aperta, non corruptione, germinare potuit saluatorem, rorantibus caelis et nubibus pluentibus iustum, id est prophetis pronuntiantibus eius aduentum».

29. De uirg., 311-312: «Haec in Ezechiele domus Dei est, cuius pudoris integerrima claustra, ad orientem consistens porta semper est clausa». 
Asimismo, en la argumentación contra la incredulidad adjudicada a los judíos, Ildefonso se sumergía de lleno en la defensa de la consustancialidad y de la doble naturaleza (humana y divina) de Cristo. En esta tarea, la patrística ya había apelado una y otra vez a la literatura profética en la búsqueda de argumentos para confrontar con la figura del judío, al cual se asociaba una negación obstinada de que Dios hubiera nacido de la Virgen en la humildad del hombre. La centralidad de Isaías se manifestaba en De uirginitate a partir de una serie de citas explícitas que daban forma a un mensaje admonitorio, dirigido a un pueblo considerado idólatra, anunciando la inminencia de su castigo. Algunos ejemplos se observan en el uso de Is 65,2: «Item Isaias: Tota die expandi manus meas ad populum non credentem et contradicentem mihi;; Is 46,12-13: "Item Isaias: Audite me duro corde et qui longe estis a iustitia: prope feci iustitiam meam, non elongabitur, et salus mea non morabitur 30 $^{30}$ y también de Is 43,8: «Item Isaias: Educ foras populum caecum et oculos habentem, surdum et aures sunt ei?.,31. En la embestida de Ildefonso, como anticipamos, Isaías no estaba solo: a sus declaraciones se sumaban las de otros profetas que, como Os $7,13^{32}$ y Jer $5,11-12^{33}$ (por nombrar solo dos ejemplos), completaban una exhaustiva estrategia ofensiva.

Ambos casos, la defensa de María y la de Cristo, habían sido construidos sobre una base escrituraria que combinaba pasajes del Antiguo y del Nuevo Testamento. El principio de unidad bíblica, como hemos mencionado, se fundaba principalmente en concebir la relación entre ambos testamentos en términos de profecía y cumplimiento. Desde esta perspectiva, Ildefonso cuestionaba a su adversario - en línea con la literatura adversus Iudaeos previa - por atenerse únicamente al pasado, a la Ley y a los Profetas, y no aceptar el Evangelio, es decir, negar el cumplimiento en el Nuevo Testamento de los vaticinios previamente anunciados. En sus palabras:

At nunc, quid uetera quaeris, quia transierunt et ecce facta sunt noua? Quid illorum temporum recordaris, propter quae facta non sunt, quoniam facta sunt propter nos, in quos fines saeculorum deuenerunt? Quid tan-

30. De uirg., 373-374 y De uirg. ,383-385.

31. De uirg., 387-388.

32. De uirg., 391-393: "Item in Osee: Vae, inquit, eis, quoniam recesserunt a me! Vastabuntur, quia praenaricati sunt in me! Ego redemi eos et ipsi locuti sunt contra me mendacium!

33. De uirg., 368-372: "Item Hieremias: Praeuaricatione praeuaricata est in me domus Iuda, ait Dominus. Negauerunt me et dixerunt: Non est ipse, quod nunc usque, Iudaee, propter hunc Christum dominum meum, huius uirginis filium, dicis "Non est ipse", expectans alium cum quo pereas, antichristum». 
tundem uaticiniis primaeuis adtendis, cum iam omne uaticinium rei gestae sit exhibitione completum? Quid de lege et prophetis agis, cum ea quae usque ad Iohannem dixerunt in Deo Christo Ihesu nostro esse completa testantur etiam rerum omnium elementa? ${ }^{34}$.

Por medio de esta cadena de interrogantes Ildefonso se disponía a objetar el cimiento argumentativo de su imaginario adversario, es decir, la versión judía del texto sagrado. Su estrategia se sustentaba principalmente en exhibir la concordancia entre ambos testamentos y en mostrar cómo diversos pasajes extraídos directamente del Antiguo Testamento constituían significativos y sólidos soportes en la defensa de la doble naturaleza de Cristo. Esta metodología — seleccionar referencias aisladas y agruparlas en función de un tema o interrogante a resolver - había sido una técnica harto difundida durante los primeros siglos del cristianismo y utilizada asiduamente desde entonces. De hecho, el uso de 'textos de prueba' constituyó en primera instancia una práctica judía, posteriormente adoptada por los exégetas cristianos de los siglos I y $\mathrm{II}^{35}$. Sin embargo, en las invectivas de Ildefonso subyacía otro propósito. Con un estilo retórico y sinonímico $^{36}$, de notoria impronta isidoriana ${ }^{37}$, Ildefonso ornamentaba sus enunciados y distanciaba su discurso de la polémica tradicional. El método de los sinónimos era explotado exhaustivamente en la construcción de los oponentes creando un mensaje repetitivo e insistente. Esto aparece bien ilustrado en la descripción del judío, elaborada sobre un bagaje terminológico en el que convergían tradiciones antijudías de períodos anteriores ${ }^{38}$. Los rasgos típicos atribuidos a este adversario - la ceguera, la obstinación, la incapacidad de comprender el verdadero sentido de las Escrituras, la dureza, el error, la maldad y la perfidia_ 39 eran presentados en cadenas

34. De uirg., 696-703.

35. Ejemplos de esta tradición en Skarsaune, The Proof y "The Development». Sobre la interacción en el plano de la exégesis véase Stemberger, «Exegetical Contacts».

36. El tratado exhibe numerosos recursos, sistemas y procedimientos literarios que evidencian un amplio manejo de la técnica sinonímica, estudiada exhaustivamente por Balleros Mateos, El tratado.

37. Acerca de los Synonyma de Isidoro de Sevilla, véase Fontaine, «Isidore de Séville» e Isidore de Séville. Genèse et originalité, 167-182; Elfassi, "La langue» y "Genèse».

38. En Hispania, González Salinero sitúa la recepción de la polémica antijudía en el curso del siglo IV con Gregorio de Elvira, Prudencio y Severo de Menorca, entre otros. González Salinero, "La polémica antijudía» y "Preaching and Jews». También en esta sección contra Iudaeos es notoria la influencia de Isidoro de Sevilla, en particular, de su obra De fide catholica. Para un estudio exhaustivo sobre Isidoro de Sevilla y los judíos véase, entre otros, Drews, The Unknown Neighbour.

39. De uirg., 227-230: "Quod enim tibi Spiritus Sanctus de illa per prophetas dixit, per oracula intimauit, per figuras innotuit, per praecedentia promisit, per subsequentia 
sinonímicas y reiterativas como en el siguiente ejemplo: «Tu autem, quem perfidia auertit, quem prauitas occupauit, quem caecitas adiit, quem error obtinuit, quem obstinatio indurauit.... ${ }^{40}$. Y más adelante, también:

De te autem propter cordis tui pessimi obstinationem, propter impuram uoluntatem, propter infidam mentem, propter conscientiam malam, propter incredulitatem iugem, propter superbiam ueram, propter oboedientiam fallacem, propter promissa infidelia, propter fidem inconstabilem audi Dominum in Deuteronomio proclamantem: «Eritis gentes ad caput, incredulus autem populus ad caudam ${ }^{41}$.

Este tipo de construcciones creaba un efecto inmediato en el lector, captando su atención a fuerza de repetición e instalando un mensaje condenatorio que crecía y se intensificaba a medida que, una tras otra y cadencia tras cadencia, las palabras envolvían al destinatario en un ritmo regular y continuo. Cada reiteración delineaba con mayor potencia los contornos del adversario, cuyos atributos se iban acumulando hasta completar su figura. Otra técnica era la concatenación de preguntas y respuestas destinada a esclarecer puntos esenciales del dogma, una estrategia eficaz al servicio de los fines pedagógicos de Ildefonso. Para cada interrogante el toledano proporcionaba las pruebas bíblicas necesarias para disipar toda duda y, una vez más, dejar en evidencia el error del otro, del adversario infiel, del judío. El despliegue de esta tecnología didáctica se puede observar con claridad, precisamente, en la sección donde Ildefonso ataca a los judíos. En efecto, allí planteaba los interrogantes centrales en torno al misterio de Cristo y enseñaba por medio de un conjunto de testimonios escriturarios las —en su lógica- verdades doctrinales. Cuándo, cómo y por qué vino Cristo eran algunas de las preguntas que se proponía esclarecer, apelando a pasajes de las Escrituras. Esta herramienta de gran valor educativo permitía encaminar el aprendizaje en la medida en que ofrecía respuestas breves, cuyo contenido era seleccionado previamente y organizado en función de proporcionar a sus lectores un conocimiento bíblico esencial.

Del repertorio de referencias veterotestamentarias, las proféticas ocupaban un lugar predominante, pues - y especialmente aquellas que invocaban el tópico del juicio final- instaban a los cristianos a evaluar su presente, su comportamiento cotidiano, y reforzar el cumplimiento y la

compleuit, te negante, te non credente, te respuente, te abnuente, te resultante, te blasphemante...".

40. De uirg., 234-236.

41. De uirg., 361-367. 
obediencia de los preceptos religiosos. Ildefonso exhortaba a creer firmemente en el nacimiento de Cristo del seno virginal y advertía que, en el caso de que esta evidente verdad no fuera aceptada, una verdad que había sido rigurosamente demostrada a partir de fundamentos bíblicos vetero- y neotestamentarios, la tierra se levantaría contra el pérfido, los cielos revelarían las iniquidades y al infierno serían arrojados. El mensaje encerraba un llamamiento directo a la comunidad, a esa comunidad que, al menos nominalmente, había aceptado a Cristo y participaba diariamente de los ritos y de las celebraciones en las iglesias, cuyos miembros habían sido bautizados e instruidos en la fe, formando parte de la ecclesia de Dios. A ella dirigía el toledano un mensaje que anhelaba arraigar en el presente de todos los cristianos, en sus hábitos, conductas, gestos y obras. Una vez más, el día del juicio - y el destino que le esperaba a toda persona que osara contradecir las verdades doctrinales - invitaba a actuar en este mundo, pues, a pesar de la cercanía de su fin, aún había tiempo para rectificar errores y volverse hacia Dios. Para esto era de importancia decisiva la acción de la Iglesia: en ella residía la tarea de comunicar la Palabra, educar a los fieles orientándolos en el camino que conducía al reino celeste y a la vida en el más allá. El clero, por lo tanto, debía estar lo suficientemente preparado, instruido en las verdades bíblicas, en la realización de sacramentos, en el cumplimiento de las obligaciones y prerrogativas correspondientes. Ellos cargaban con una responsabilidad mayor y a ellos también —o a ellos sobre todo- iba dirigido el mensaje admonitorio del profeta, aquel que, prometiendo para el infiel un destino tortuoso y aterrador, no dejaba de prometer la salvación para el que no se dejaba corromper ni desviar de la verdadera $\mathrm{fe}^{42}$.

Del Nuevo Testamento, las referencias procedían principalmente del corpus evangélico. Ejemplos de esta estrategia se observan en el uso de Mt 26,64: «QQuare non credis Filio dicenti: Amodo uidebitis filium bominis sedentem a dextris uirtutis Dei, cum Pater illi dicat: Sede a dextris meis? ${ }^{43}$

42. De uirg., praef. 78-86: «Veniet prorsus, ueniet, nec longe est; ueniet de proximo, ueniet de uicino. Sed cum exarserit in breui, cum uenerit in maiestate, cum fuerit in circuitu eius tempestas ualida, cum ante eum praecesserit ignis, tunc beati omnes qui illum ueraciter diligunt, beati qui de illo uera dicunt, beati qui ueritatem non spernunt, beati qui faciunt in ueritate iustitiam, beati qui custodiunt in ueritate iudicium, et beati omnes qui confidunt in eum. Iudex enim ueniet, districtus occurret, metuendus aderit, terribilis apparebit». La afirmación de la cercanía del Juicio parecía en principio transmitir una visión alarmante e inminente del fin del mundo. Sin embargo, este mensaje —amenazante para algunos- encerraba una promesa de felicidad para otros. Una vez más, la repetición y la sinonimia aparecían para dar forma ya no al adversario, sino a ese otro conjunto de selectos o beati destinados a transitar el camino hacia la eterna beatitud.

43. De uirg., 772-774. 
y Mc 13,26-27: "Quare non credis uenturum iudicem Marco dicenti: Tunc uidebunt filium hominis uenientem in nubibus cum uirtute multa et gloria, et congregabit electos suos? ${ }^{44}$. Una vez más era reforzada la noción de Cristo como juez de la humanidad y la existencia de un conjunto de hombres, los elegidos, los únicos destinados a alcanzar el goce de la vida futura. El papel de Cristo en el Juicio era apuntalado a partir de Sal 49,4-6, al invocar las palabras del rey ungido:

Hoc enim est quod et Dauid dicit: Aduocabit caelos sursum et terram discernere populum suum. Congregate illi sanctos eius, qui ordinent testamentum eius super sacrificia. Et adnuntiauerunt caeli iustitiam eius, quoniam Deus iudex est ${ }^{45}$.

Esta concatenación de testimonios escriturarios exhibía, por un lado, la existencia de una única interpretación del texto sagrado: tanto el inicio de la creación como el ocaso del mundo y el advenimiento del reino de los cielos había sido dispuesto de un solo modo por la divinidad.

La demostración a través de los profetas y de los evangelistas asumía una relevancia destacada, pues garantizaba la unidad entre los testamentos y la continuidad de la Palabra de Dios. La voz profética — dado su carácter admonitorio e invectivo- se adecuaba bien a los parámetros del capítulo Contra Iudaeos destinado a enseñar las diferencias entre la verdadera y la falsa doctrina. Indicar las discrepancias, contrastes e incompatibilidades entre una y otra era también un modo de instruir a la comunidad. La construcción del adversario - concentrando en su imagen todos los atributos negativos que desde antiguo caracterizaban al infiel, al que abandona a Dios- actuaba, asimismo, como factor de unidad para todos aquellos que, por el contrario, se aferraban a la fe y a los preceptos cristianos. El clero y, por extensión, las comunidades que dependían de su autoridad encontraban allí el contramodelo por excelencia, repudiado y condenado, pero, al mismo tiempo, sumamente necesario por su efecto aglutinador: contra la acción disgregadora del oponente, la ecclesia era presentada como unida en Cristo, en - y por - la Iglesia. El inevitable advenimiento de Cristo en su condición de juez y el porvenir reservado a herejes e infieles debían de infundir la cuota de temor necesaria para que la comunidad cristiana en general y los encargados de su orientación en particular optaran por una rigurosa disciplina, la obediencia y la austeridad.

44. De uirg., 1010-1012.

45. De uirg., 1013-1016. 


\section{LOS DESTINATARIOS DEL DE UIRGINITATE}

Una de las preguntas más difíciles de responder en relación al estudio del De uirginitate es a quién estaba destinado el texto. En realidad el destinatario inicial es relativamente fácil de detectar: el clero. Como hemos anticipado, Ildefonso se puso a la cabeza de aquello que concebía como una tarea necesaria en su época: instruir al cuerpo eclesiástico. Porque, aunque sea una obviedad repetirlo, la población no leía los textos producidos por las elites religiosas.

Pero más allá de esta respuesta inicial, Ildefonso debió haber tenido en mente un objetivo. Es decir, preparó al clero para que este, a su vez, instruyera a la población. Allí sí es más difícil dirimir qué buscaba exactamente el hombre de Agali.

Se han ensayado múltiples respuestas en relación al auditorio final imaginado por Ildefonso en el De uirginitate, las cuales pueden condensarse en tres grandes líneas: 1) los judíos; 2) los cristianos que habían sido judíos; 3) los cristianos sin pasado judío. Si bien pensamos, como ya adelantamos, que los destinatarios finales (si bien no los únicos) del texto fueron los cristianos, es válido aceptar que todas las respuestas presentadas tienen sentido y, a su vez, ninguna (ni siquiera la que aquí proponemos) es suficientemente categórica dado que las propias características de la fuente impiden ir más allá de la conjetura. Antes de exponer nuestra posición, vale hacer un breve recorrido por las interpretaciones previas del texto.

Comencemos por la introducción a la edición más reciente del De uirginitate, donde Yarza Urquiola considera que:

En realidad, los capítulos del De uirginitate destinados a rebatir los argumentos de Joviniano y Helvidio no son sino dos brevísimos alegatos que dan entrada a la diatriba contra el verdadero adversario, los judíos ${ }^{46}$.

El editor, de hecho, se apoyaba en una larga tradición ${ }^{47}$ que incluía, entre otros, a Lorenzana ${ }^{48}$, Menéndez Pelayo ${ }^{49}$, Braegelmann ${ }^{50}$,

46. Yarza Urquiola, De uirginitate, 31. En una línea similar, Martín-Iglesias, «Ildefonso de Toledon, 131.

47. Yarza Urquiola, De uirginitate, 27-41, realiza un pormenorizado estado de la cuestión sobre el tema.

48. Lorenzana, Hildefonsi, col. 52. También consideraba la posible existencia de seguidores no judíos de doctrinas como las de Joviniano y Helvidio (c. 51-2). Esta mirada se replicó también en Menéndez Pelayo y en Madoz.

49. Menéndez Pelayo, Historia, 263.

50. Braegelmann, The Life. 
Madoz $^{51}$, Cascante ${ }^{52}$, Hernández ${ }^{53}$, Díaz y Díaz ${ }^{54}$, Rivera Recio ${ }^{55}$, García Moreno $^{56}$, Carrete Parrondo ${ }^{57}$ y Colomina Torner $^{58}$.

En oposición a la idea de que el De uirginitate hubiese tenido como destinatario un auditorio judío (o converso) encontramos a Williams quien, ya en los 30, había sostenido explícitamente que los destinatarios no habían sido los judíos sino los cristianos sin pasado judío ${ }^{59}$. Domínguez del Val, por su parte, consideró que el texto estaba especialmente orientado a la mera exaltación del culto mariano ${ }^{60}$. Schreckenberg, aunque muy someramente, sugirió que, más allá de que los judíos ocuparan una parte central del De uirginitate, los destinatarios habrían sido cristianos $^{61}$. Gil fue más ambiguo, iluminando el carácter atemporal del judío constituido como adversario, aunque en un trabajo en el que ponía en primer plano la presencia judía y el peso del mesianismo como motor de una gran efervescencia (y visibilidad) de los judíos ${ }^{62}$.

Algunos autores insinuaron la existencia de más de un objetivo. De hecho, algunos de los recién nombrados también aceptaron que podía existir más de un fin en el texto. Blumenkranz, sin dudarlo, consideró que el texto apuntaba tanto a los judíos que nunca habían sido forzosamente convertidos como a los nuevos cristianos con pasado judío ${ }^{63}$. En una línea similar se ubicaron, en tiempos más cercanos, Pozas Garza ${ }^{64}$ y González Salinero ${ }^{65}$.

Más recientemente, Ihnat, en un estudio dedicado a la liturgia mariana en Hispania y a su estrecha conexión con el De uirginitate, propuso

51. Madoz, "San Ildefonso", 490-491.

52. Cascante, Doctrina mariana, 15-20. En otro trabajo ("El tratado») Cascante no se pronuncia sobre los destinatarios de modo específico.

53. Hernández, «El problema», 116-117.

54. Díaz y Díaz, "La obra literaria», 57.

55. Rivera Recio, «Los arzobispos», 194-195, y San Ildefonso, 169.

56. García Moreno, Los judíos, 121. El autor, de todos modos, apenas se pronuncia sobre el tema y realiza una sugerencia acerca del posible destinatario del texto.

57. Carrete Parrondo, "Polémica judeo-cristiana", 32.

58. Colomina Torner, «El antijudaísmo», 188-189. Además de los judíos, Colomina Torner creía que en Hispania podía haber cristianos que utilizaran los argumentos de Joviniano y Helvidio. Para ello citaba el sínodo romano de 649.

59. Williams, Adversus Judaeos, 219

60. Domínguez del Val, "Personalidad y herencia», 297-299.

61. Schreckenberg, Die christlichen, 447-449.

62. Gil, "Judíos y cristianos", 73-74.

63. Blumenkranz, Les auteurs, 111-116.

64. Pozas Garza, Estudio crítico, 71. En la misma línea, Pozas Garza y Moreno García, "Una controversia», 110-112.

65. González Salinero, Las conversiones, 97-98. 
vincular determinados aspectos del culto directamente con los neoconversos provenientes desde el judaísmo ${ }^{66}$.

Pero volvamos ahora al estudio de Yarza Urquiola quien sostiene, luego de afirmar el objetivo antijudío del tratado: «Quiénes no eran católicos en Toledo sino los judíos? ${ }^{67}$. En esta pregunta radica, entendemos, una de las confusiones en las que solemos caer quienes investigamos la literatura adversus Iudaeos. Porque la pregunta, en realidad, es problemática. Sería más apropiado, tal vez, el siguiente interrogante: ¿Quiénes no se comportaban como católicos en Toledo según Ildefonso? Y la respuesta es, aunque suene paradójico, los propios cristianos. Gran parte de la literatura tardoantigua se basa en esta lógica: el obispo intenta, con sus discursos, que los cristianos se comporten como él considera que deben comportarse. Y las figuras espectrales de herejes, judíos e, incluso, ángeles operan para mostrar lo incorrecto y lo correcto.

Afirmar que el objetivo principal de Ildefonso fueron los cristianos no implica negar que esta meta incluía a quienes se habían convertido forzosamente desde el judaísmo. Entendemos que no era su objetivo principal, pero seguramente estuvo entre sus preocupaciones. Podemos, de hecho, invertir los términos de Blumenkranz e Ihnat. Porque los neoconversos seguramente estuvieron en las consideraciones de Ildefonso al momento de constituir el De uirginitate. Pero la preocupación estuvo, según nuestra perspectiva, en los cristianos sin pasado judío. El refuerzo del culto mariano pudo haber funcionado como una especie de profilaxis discursiva ante dudas que pudieron difundir, voluntaria pero sobre todo involuntariamente, aquellos cristianos que habían sido judíos ${ }^{68}$. O, directamente, a dudas que pudieron albergar los cristianos, sin influencia alguna de gentes con pasado judío ${ }^{69}$.

66. Ihnat, «Liturgy», 446 y 464-465.

67. Yarza Urquiola, De uirginitate, 36.

68. De un modo similar, se ha sostenido que el De fide de Isidoro pudo haber sido concebido para evitar confusiones entre los cristianos sin pasado judío en un tiempo en el que Sisebuto había forzado a ingresar a la cristiandad a un número importante de judíos (Laham Cohen, "Entre la represión» y "El De Fide Catholica»). Sin embargo, González Salinero data la confección del tratado en un tiempo anterior a la conversión masiva y rechaza esta idea (González Salinero, "Confronting the Other», 378-379).

69. El interés por educar al clero y a la comunidad de fieles en general atraviesa también otras obras atribuidas a Ildefonso de Toledo. En un escrito actualmente conocido como De cognitione baptismi, elaborado durante su episcopado (656-667), el toledano se propuso transmitir los puntos fundamentales del sacramento bautismal, su importante significado como rito de iniciación cristiana y su correcta administración y, además, repasar y enseñar contenidos doctrinales y litúrgicos esenciales en la preparación de los neófitos. Allî́ también, una vez más, era resaltado el papel del obispo, y de la Iglesia, en la formación 
Es que imaginar que todo el tratado de Ildefonso se orientó exclusivamente a los neoconversos implica, de algún modo, sobrevalorar el peso demográfico de estos en el reino visigodo. Ciertamente no contamos con datos fidedignos para ponderar la cantidad de judíos y judías que habían sido convertidos/as, pero es poco probable que su cantidad haya sido tan grande como para impactar no solo en el De uirginitate, sino también en la propia liturgia visigoda ${ }^{70}$.

Ahora bien, ¿qué sucede con aquellos judíos que nunca habían sido sometidos a la conversión? Según nuestra perspectiva, si bien Ildefonso debió de estar al tanto de la supervivencia de judíos, su obra no estuvo destinada a ellos. De hecho, aunque declara disputar contra los judíos en base al texto testamentario compartido, apela también a pruebas neotestamentarias. Vale recordar que quienes no habían sido convertidos tenían muchas menos posibilidades de llegar al discurso construido por el hombre de Agali. Nuevamente, eran los cristianos, con y sin pasado judío, los destinatarios finales del mensaje.

Más allá de nuestras hipótesis sobre el auditorio específico, en estas páginas hemos observado la implementación de las figuras de los herejes y del judío - y del adversario en general- como un dispositivo pedagógico, de construcción y afirmación de la identidad cristiana. Esta relación negativa con el otro, de exclusión, oposición y contraste, habilitaba como contrapartida la consolidación de un nosotros, de una comunidad que se veía a sí misma unida bajo una sola religión y una sola monarquía.

Al embestir duramente contra los judíos —más allá de si lo hizo contra judios hermenéuticos, reales o «bautizados»- Ildefonso enseñaba las fronteras de lo correcto y lo incorrecto, posicionándose, además, como una auctoritas en la materia.

y orientación de los fieles, en el desarrollo y homogeneización de las prácticas, los sacramentos y los valores considerados propios de una vida acorde a los preceptos cristianos. La enseñanza y la persuasión eran las herramientas esenciales de un clero que buscaba reforzar la identidad católica del reino, y de la diócesis toledana en particular, transmitiendo los pilares, los saberes y las conductas que debían adoptar aquellos que habiendo recibido el bautismo comenzaban a transitar el camino que los conduciría a la vida eterna.

70. Es cierto que en cuanto al interrogante demográfico, la documentación resulta escasa tanto para afirmar como para negar la existencia de una comunidad judía de gran tamaño en el reino visigodo, especialmente en la capital. Advertimos, por lo tanto, las dificultades implícitas en este argumento. Asimismo, no es nuestra intención negar la presencia judía ni la coexistencia en Toledo de cristianos, judíos y conversos. De hecho, hemos señalado ya los esfuerzos regios y episcopales por hacer frente a esta cuestión. Sin embargo, la problemática que nos interesa abordar aquí se vincula más con los mecanismos y dispositivos que, empuñados por el alto clero visigodo, fueron desplegados para enseñar y proyectar una identidad cristiana que afirmara y consolidara la unidad de un reino cristiano. 


\section{CONCLUSIONES}

Durante la segunda mitad del siglo VII la cuestión judía continuaba vigente en la agenda episcopal y monárquica, retomada una y otra vez por los altos dignatarios del reino de Toledo. Indicios de su actualidad encontramos, por ejemplo, en las actas conciliares o en el código legislativo impulsado por Recesvinto. Con De uirginitate Ildefonso se sumaba a las iniciativas regias y episcopales, abordando interrogantes inmediatos que concernían a un reino cristiano inmerso en lo que se percibían como peligros asociados al judaísmo. No solo al judaísmo sino a toda posición, incluso cristiana, que fuera disonante respecto de la línea planteada por la monarquía y la Iglesia visigoda. Ildefonso, frente a este panorama, retomaba la tradición y volvía a activar en su tiempo los arquetipos eclesiásticos de la perfidia: heresiarcas y judíos.

Como vimos, estos desempeñaron un importante papel. Por un lado, en el plano de la enseñanza doctrinal, funcionaron como verdaderos dispositivos pedagógicos en tanto que, asociados al error, al engaño y a la falsedad, constituían los contraejemplos por excelencia. En este sentido, Ildefonso retomaba estas creencias para visibilizar y señalar el error e impartir el verdadero mensaje basado en la correcta interpretación de la revelación divina. Esta tarea conllevaba la selección y organización del contenido bíblico, la elección del material sagrado que se deseaba enseñar y difundir entre los miembros de la comunidad. Por lo tanto — más allá de si existía una amenaza real personificada en la presencia de núcleos poblacionales de conversos anteriormente judíos y superficialmente cristianizados o directamente judíos-, la implementación discursiva del judío y de su creencia funcionó como herramienta en los diversos procesos involucrados en la construcción y afianzamiento de una comunidad alrededor de una sola fe y de una sola Iglesia. La obra de Ildefonso, como tantas otras producidas en el seno de las elites eclesiásticas visigodas, se proponía intervenir fundamentalmente en los círculos cristianos ya sea para fortalecer la doctrina o bien para evitar la propagación de errores, tergiversaciones o desviaciones de la fe erigida como ortodoxa. Por otro lado, las embestidas dirigidas a Helvidio, Joviniano y al judío en defensa de la virginidad de María permitieron también fomentar el culto mariano desde Toledo, exaltando la figura de la Virgen, que emergía con extraordinaria potencia como símbolo de identidad y unidad cristiana. Una vez más, en De uirginitate, movimientos ofensivos y defensivos se complementaban para afianzar los lazos que unían a la Iglesia con la comunidad. 
6. Bibliografía

Bachrach, Bernard S. "A Reassessment of Visigothic Jewish Policy, 589711». The American Historical Review 78/1 (1973): 11-34.

Balleros Mateos, Juana. El tratado "De virginitate Sanctae Mariae" de San Ildefonso de Toledo: Estudios sobre el estilo sinonímico latino. Toledo: Estudio Teológico de San Ildefonso, 1985.

Bar-Magen Numhauser, Alexander. "La identificación de la sinagoga de Ilici. Replanteando un urbanismo paleocristiano peninsular desde la arqueología judía». En Tarraco Biennal. Actes 4 t Congrés Internacional d'Arqueologia $i$ Món Antic. VII Reunió d'Arqueologia Cristiana Hispànica: el cristianisme en l'Antiguitat Tardana. Noves perspectives, editado por Jordi López Vilar, 297-304. Tarragona: Universitat Rovira i Virgili - Institut d'Estudis Catalans, 2019.

Beltrán Torreira, Federico-Mario. "San Ildefonso de Toledo y el culto a la virgen en la Iglesia Hispano-visigoda: problemas históricos y doctrinales». En Devoción mariana y sociedad medieval: Actas del simposio [Ciudad Real del 22 al 24 de marzo, 1989], 439-454. Ciudad Real: Instituto de Estudios Manchegos, 1990.

Benveniste, Henriette-Rika. "On the Language of Conversion: Visigothic Spain Revisited». Historein 6 (2006): 72-87. https://doi.org/10.12681/ historein. 61

Biddick, Kathleen. "Paper Jews: Inscription/Ethnicity/Ethnography». The Art Bulletin 78/4 (1996): 594-599.

Blumenkranz, Bernhard. Les auteurs chrétiens du Moyen Age sur les juifs et le judaïsme. París-La Haya: Mouton \& Co, 1963.

Bradbury, Scott. "The Jews of Spain: C. 235 - 638». En The Cambridge History of Judaism IV, editado por Steven Katz, 508-518. Cambridge: Cambridge University Press, 2006.

Braegelmann, Athanasius. The Life and Writings of Saint Ildefonsus of Toledo. Washington: The Catholic University of America, 1942.

Brubaker, Leslie y Mary B. Cunningham, eds. The Cult of the Mother of God in Byzantium. London-New York: Routledge, 2016.

Carleton Paget, James y Joachim Schaper, eds. The New Cambridge History of the Bible: From the Beginnings to 600. Cambridge: Cambridge University Press, 2013.

Carrete Parrondo, Carlos. «Polémica judeo-cristiana en los Reinos hispánicos». Revista Española de Filosofía Medieval 3 (1996): 31-36. https:// doi.org/10.21071/refime.v3i.9715

Cascante, Juan María. Doctrina mariana de S. Ildefonso de Toledo. Barcelona: Editorial Casulleras, 1958. 
Cascante, Juan María. "El tratado 'De Virginitate' de S. Ildefonso de Toledo". En La patrología toledano-visigoda. XXVII Semana Española de Teología (Toledo, 25-29 sept. 1967), 349-368. Madrid: CSIC, 1970.

Castro, Dolores. "The Bishop and the Word. Isidore of Seville and the Production of Meaning». En Framing Power in Visigothic Society. Discourses, Devices, and Artefacts, editado por Eleonora Dell'Elicine y Céline Martin, 51-74. Amsterdam: Amsterdam University Press, 2020.

Cazier, Pierre. Isidore de Séville et la naissance de l'Espagne catholique. Paris: Beauchesne, 1994.

Codoñer Merino, Carmen. «El mundo cultural de Isidoro de Sevilla». En San Isidoro: Doctor Hispaniae, editado por Julián González Fernández, 97-111. Sevilla: Fundación el Monte, 2002.

Codoñer Merino, Carmen, coord. La Hispania visigótica y mozárabe. Dos épocas en su literatura. Salamanca: Ediciones Universidad de Salamanca, 2010.

Cohen, Jeremy. Living Letters of the Law: Ideas of the Jew in Medieval Christianity. Berkeley: University of California Press, 1999.

Colomina Torner, Jaime. «El antijudaísmo hispanogodo y sus posibles ecos en los textos litúrgicos e ildefonsinos". En La controversia judeocristiana en España (Desde los orígenes hasta el siglo XIII). Homenaje a Domingo Muñoz León, editado por Carlos del Valle Rodríguez, 171190. Madrid: CSIC, 1998.

Cordero Navarro, Catherine. «El problema judío como visión del 'otro' en el reino visigodo de Toledo. Revisiones historiográficas». En la España Medieval 23 (2000): 9-40.

Dell'Elicine, Eleonora. En el principio fue el Verbo. Políticas del signo y estrategias del poder eclesiástico en el reino visigodo de Toledo (589711). Cádiz: Universidad de Cádiz, 2013.

Del Valle Rodríguez, Carlos. «El tratado de la virginidad perpetua de Santa María de Ildefonso de Toledo". En La controversia judeocristiana en España (Desde los orígenes hasta el siglo XIII). Homenaje a Domingo Muñoz León, editado por Carlos del Valle Rodríguez, 115-118. Madrid: CSIC, 1998.

Díaz y Díaz, Manuel C. «La obra literaria de los obispos visigóticos toledanos». En La patrología toledano-visigoda. XXVII Semana Española de Teología (Toledo, 25-29 sept. 1967), 45-63. Madrid: CSIC, 1970.

Domínguez del Val, Ursicino. "Personalidad y herencia literaria de S. Ildefonso de Toledo». Revista Española de Teología 31 (1971): 137-166.

Drews, Wolfram. The Unknown Neighbour: The Jew in the Thought of Isidore of Seville. Leiden: Brill, 2006. 
Elfassi, Jacques. «La langue des 'Synonyma' d'Isidore de Séville». Bulletin Du Cange 62 (2004): 59-100.

Elfassi, Jacques. "Genèse et originalité du style synonymique dans les 'Synonyma' d'Isidore de Séville». Revue des études latines 83 (2006): 226-245.

Fear, Andrew y Jamie Wood, eds. Isidore of Seville and his Reception in the early Middle Ages. Amsterdam: Amsterdam University Press, 2016.

Fear, Andrew y Jamie Wood, eds. A Companion to Isidore of Seville. LeidenBoston: Brill, 2020.

Fontaine, Jacques. Isidore de Séville et la culture classique dans l'Espagne wisigothique. Paris: Études Augustiniennes, 1959.

Fontaine, Jacques. «Isidore de Séville auteur ascétique: les énigmes des Synonyma». Studi medievali 6 (1965): 163-195.

Fontaine, Jacques. Isidore de Séville. Genèse et originalité de la culture hispanique au temps des Wisigoths. Turnhout: Brepols, 2000.

Fredriksen, Paula. "Roman Christianity and the Post-Roman West: The Social Correlates of the Contra Iudaeos Tradition». En Jews, Christians, and the Roman Empire. The Poetics of Power in Late Antiquity, editado por Natalie Dohrmann y Annette Yoshiko Reed, 249-266. Philadelphia: University of Pennsylvania Press, 2013.

García Iglesias, Luis. Los judios en la España antigua. Madrid: Ediciones Cristiandad, 1978.

García Moreno, Luis A. Los judíos de la España antigua. Madrid: Rialp, 1993.

Gil, Juan. «Judíos y cristianos en la Hispania del siglo VII». Hispania Sacra 30 (1977): 9-110.

González Salinero, Raúl. «Los judíos y la gran propiedad en la Hispania tardoantigua: el reflejo de una realidad en la Passio Mantii,. Gerión 16 (1998): 437-450.

González Salinero, Raúl. Las conversiones forzosas de los judios en el reino visigodo. Roma: Escuela Española de Historia y Arqueología, 2000.

González Salinero, Raúl. "La polémica antijudía en la Hispania tardoantigua y visigoda: resultados y perspectivas de una línea de investigación consolidada». Mainake XXXI (2009): 123-129.

González Salinero, Raúl. Infelix Ivdaea. La polémica antijudia en el pensamiento histórico-político de Prudencio. Madrid: CSIC, 2010.

González Salinero, Raúl. "Preaching and Jews in Late Antiquity and Visigothic Iberia». En The Jewish-Christian Encounter in Medieval Preaching, editado por Jonathan Adams y Jussi Hanska, 23-58. New York: Routledge, 2015. 
González Salinero, Raúl. «El obispo y los judíos». En El obispo en la Antigüedad Tardía. Homenaje a Ramón Teja, editado por Silvia Acerbi, Mar Marcos y Juana Torres, 169-186. Madrid: Trotta, 2016.

González Salinero, Raúl. «Confronting the Other: Isidore of Seville on Pagans, Romans, Barbarians, Heretics, and Jews». En A Companion to Isidore of Seville, editado por Andrew Fear y Jamie Wood, 359-393. Leiden: Brill, 2020.

Hernández, Ramón. «El problema de los judíos en los PP. Visigodos». En La patrología toledano-visigoda. XXVII Semana Española de Teología (Toledo, 25-29 sept. 1967), 99-120. Madrid: CSIC, 1970.

Hunter, David G. "Resistance to the Virginal Ideal in the Late-FourthCentury Rome: The Case of Jovinian». Theological Studies 48 (1987): 45-64.

Hunter, David G. «Helvidius, Jovinian, and the Virginity of Mary in Late Fourth-Century Rome». Journal of Early Christian Studies 1, n. ${ }^{\circ} 1$ (1993): 47-71. https://doi.org/10.1353/earl.0.0147

Hunter, David G. Marriage, Celibacy, and Heresy in Ancient Christianity. The Jovinianist Controversy. Oxford: Oxford University Press, 2007.

Hurley, Michael. «Born Incorruptibly: The Third Canon of the Lateran Council (A.D. 649)». Heythrop Journal 2 (1961): 216-226. https://doi. org/10.1111/j.1468-2265.1961.tb00263.x

Ibáñez, Javier y Fernando Mendoza. "María Madre de Jesús y Madre de la Iglesia en la perspectiva teológica de la liturgia visigótica». Scripta Theologica 3 (1971): 343-421.

Ihnat, Kati. "Liturgy against Apostasy: Marian Commemoration and the Jews in Visigothic Iberia». Early Medieval Europe 25/4 (2017): 443-465. https://doi.org/10.1111/emed.12227

Ihnat, Kati. «Orígenes y desarrollo de la fiesta litúrgica de la virgen María en Iberia». Anuario de Estudios Medievales 49/2 (2019): 619-643. https://doi.org/10.3989/aem.2019.49.2.09

Kelly, John N. D. Jerome: His Life, Writings and Controversies. London: Harper \& Row, 1975.

Kruger, Steven. The Spectral Jew: Conversion and Embodiment in Medieval Europe. Mineápolis: University of Minnesota Press, 2006.

Laham Cohen, Rodrigo. "Entre la represión y la tolerancia. El derrotero de los judíos en tiempos de Gregorio Magno e Isidoro de Sevilla». Trabajos y Comunicaciones 36 (2010): 13-35.

Laham Cohen, Rodrigo. «El De Fide Catholica de Isidoro de Sevilla en el marco de la disputa aduersus Iudaeos". En ¿Qué implica ser medievalista? Prácticas y reflexiones en torno al oficio del historiador, n. ${ }^{\circ}$ II, 
editado por Vanina Neyra y Gerardo Rodríguez, 5-21. Mar del Plata: Universidad Nacional de Mar del Plata, 2012.

Laham Cohen, Rodrigo y Carolina Pecznik. "Iudaei et Iudaei baptizati en la ley de los visigodos». Anuario de la Escuela de Historia 28 (2016): 141-169. http://anuariodehistoria.unr.edu.ar/ojs/index.php/Anuario/ article/view/192/213

Lorenzana, Francisco, ed. Hildefonsi opera monitum. De Perpetua Deiparae Virginitate (PL 96). Paris, 1862.

Madoz, José. "San Ildefonso de Toledo». Estudios Eclesiásticos 26 (1952): 467-505.

Martin, Céline. La géographie du pouvoir dans l'Espagne visigothique. Lille: Septentrion, 2003.

Martin, Céline. "La degradación cívica de los judíos en el reino visigodo de Toledo". En Marginados sociales y religiosos en la Hispania tardorromana y visigoda, editado por Raúl González Salinero, 221-241. Madrid-Salamanca: Signifer, 2013.

Martin, Céline. «Los judíos y la peste: la excepción narbonense a la persecución de 694». Temas Medievales 25 (2017): 83-101.

Martin, Céline y Capucine Nemo-Pekelman. "Les Juifs et la cité. Pour une clarification du statut personnel des juifs de l'Antiquité Tardive à la fin du royaume de Tolède (IVe-VII ${ }^{e}$ siècles)». Antiquité Tardive 16 (2008): 1-24. https://doi.org/10.1484/J.AT.3.17

Martín, José Carlos. «La biblioteca cristiana de los Padres hispanovisigodos (siglos VI-VII)». Veleia 30 (2013): 259-288.

Martín-Iglesias, José Carlos. «Ildefonso de Toledo. La Hispania visigótica y mozárabe. Dos épocas en su literatura». En La Hispania visigótica y mozárabe. Dos épocas en su literatura, coordinado por Carmen Codoñer Merino, 129-139. Salamanca: Ediciones Universidad de Salamanca, 2010.

Maunder, Chris, ed. The Oxford Handbook of Mary. Oxford: Oxford University Press, 2019.

Meerson, Michael y Peter Schäfer, eds. y trads. Toledot Yeshu. The Life Story of Jesus. Tübingen: Mohr Siebeck, 2014.

Menéndez Pelayo, Marcelino. Historia de los heterodoxos españoles. Madrid: La Editorial Católica, 1880.

Muñoz León, Domingo. "El uso de la Biblia en el Tratado 'De virginitate perpetua Sanctae Mariae' de San Ildefonso de Toledo". Estudios Marianos 55 (1990): 251-285.

Orlandis, José. «Hacia una mejor comprensión del problema judío en el reino visigodo-católico de España». En Gli ebrei nell'alto medioevo. 
Settimane di Studio del Centro Italiano di Studi sull'Alto Medioevo XXVI, 149-178. Spoleto: CISAM, 1980.

Poveda Navarro, Antonio. "El edificio de culto de 'La Ancudia' de Elche: ¿sinagoga o basílica? Un siglo de debates». En ¿Una Sefarad inventada? Los problemas de interpretación de los restos materiales de los judios en España, editado por Javier Castaño, 161-179. Córdoba: El Almendro, 2014.

Pozas Garza, Raúl. Estudio crítico de los tratados "adversus Iudaeos" en la Alta Edad Media. Roma: Ponti cium Athenaeum Sanctae Crucis, 1996.

Pozas Garza, Raúl y Abdón Moreno García. «Una controversia judeo-cristiana del s. VII: De virginitate perpetua Sanctae Mariae contra tres infideles de Ildefonso de Toledo". Anales Valentinos 31/61 (2005): 107-128.

Rivera Recio, Juan Francisco. "Los arzobispos de Toledo en el siglo VII". Anales Toledanos 3 (1983): 181-218.

Rivera Recio, Juan Francisco. San Ildefonso de Toledo. Biografía, época y posteridad. Madrid-Toledo: Biblioteca de Autores Cristianos, 1985.

Rubin, Miri. Mother of God. A History of the Virgin Mary. New HavenLondon: Yale University Press, 2009.

Schreckenberg, Heinz. Die christlichen Adversus-Judaeos-Texte und ibr literarisches und historisches Umfeld (1.-11.Jh.). Frankfurt: Peter Lang, 1982.

Shoemaker, Stephen J. Mary. In Early Christian Faith and Devotion. New Haven: Yale University Press, 2016.

Sivan, Hagith. "The invisible Jews of Visigothic Spain». Revue des Etudes Juives 159 (2000): 369-385. https://doi.org/10.2143/REJ.159.3.165

Skarsaune, Oskar. The Proof From Prophecy. A Study in Justin Martyr's Proof-Text Tradition: Text Type, Provenance, Theological Profile. Leiden: Brill, 1987.

Skarsaune, Oskar. «The Development of Scriptural Interpretation in the Second and Third Centuries - except Clement and Origen". En Hebrew Bible/ Old Testament. The History of its Interpretation, vol. 1, editado por Magne Sæbø, 373-440. Göttingen: Vandenhoeck \& Ruprecht, 1996. Stemberger, Günter. «Exegetical Contacts Between Christians and Jews in the Roman Empire». En Judaica Minora, editado por Günter Stemberger, 432-451. Tübingen: Mohr Siebeck, 2010.

Stocking, Rachel. "Early Medieval Christian Identity and Anti-Judaism. The Case of the Visigothic Kingdom». Religion Compass 2/4 (2008): 642658.

Tomasch, Sylvia. "Postcolonial Chaucer and the Virtual Jew». En The Postcolonial Middle Ages, editado por Jeffrey Cohen, 243-260. New York: Palgrave Macmillan, 2000. 
Trebolle Barrera, Julio. La Biblia judia y la Biblia cristiana. Introducción a la bistoria de la Biblia. Madrid: Trotta, 1998.

Velázquez, Isabel y Gisela Ripoll. "Toletum, la construcción de una urbs regia». En Sedes regiae (ann. 400-800), editado por Gisela Ripoll y Josep María Gurt Esparraguera, 521-578. Barcelona: Real Acadèmia de Bones Lletras, 2000.

Walsh, Robyn. "Reconsidering the Synagogue/Basilica of Elche, Spain". Jewish Studies Quarterly 23/2 (2016): 91-123. https://doi.org/10.1628/0 94457016 X14781655923274

Williams, A. Lukyn. Adversus Iudaeos. A Bird's-Eye View of Christian Apologiae until the Renaissance. Cambridge: Cambridge University Press, 2012 [1935].

Yarza Urquiola, Valeriano. "De uirginitate Sanctae Mariae». En Ildefonsi Toletani episcopi De virginitate Sanctae Mariae, De cognitione baptismi, De itinere deserti, De viris illustribus (CCSL 114A), editado por Valeriano Yarza Urquiola y Carmen Codoñer. Turnhout: Brepols, 2007. 